\title{
Addition of calcium and magnesium chlorides as simple means of varying bound and precipitated minerals in casein micelle: Effect on enzymatic coagulation
}

\author{
J. Bauland, ${ }^{1,2} \odot$ M. H. Famelart, ${ }^{1} \odot$ S. Bouhallab, ${ }^{1}$ R. Jeantet, ${ }^{1}$ S. Roustel, ${ }^{2}$ M. Faiveley, ${ }^{2}$ and T. Croguennec ${ }^{1 *} \odot$ \\ ${ }^{1}$ Science et Technologie du Lait et de l'Oeuf (STLO), INRAE, Institut Agro, 35042 Rennes, France \\ ${ }^{2} \mathrm{Chr}$. Hansen, 2970 Hoersholm, Denmark
}

\begin{abstract}
In casein micelle $(\mathrm{CM}), \mathrm{Ca}$ is either precipitated in the colloidal calcium phosphate (CCP) stabilized by clusters of phosphoserine (SEP) residues, or is directly bound to SEP (or glutamic and aspartic acids) of caseins without inorganic phosphate. However, it is currently not possible to titrate separately the different micellar Ca forms, making it difficult to assess their respective importance for $\mathrm{CM}$ properties and behavior. Both $\mathrm{Ca}^{2+}$ and $\mathrm{Mg}^{2+}$ have the same binding constants with SEP. Moreover, $\mathrm{MgHPO}_{4}$ is more soluble than $\mathrm{CaHPO}_{4}$, and its natural concentration in milk is lower. Thus, upon addition of $\mathrm{MgCl}_{2}, \mathrm{Mg}$ is mainly exchanged with $\mathrm{CM}$ in the bound form, whereas upon addition of $\mathrm{CaCl}_{2}, \mathrm{Ca}$ is mainly exchanged in the precipitated form. Our objective was to assess the role of the 2 forms of micellar cations (bound and precipitated) during the enzymatic coagulation of cow milk. Magnesium chloride, $\mathrm{CaCl}_{2}$, or $\mathrm{KCl}(10 \mathrm{mM})$ were added to milk and $\mathrm{pH}$ was adjusted to 6.6 after overnight equilibration. The KCl-supplemented milk was a positive control to assess the effect of the increased ionic strength after $\mathrm{MgCl}_{2}$ and $\mathrm{CaCl}_{2}$ addition. Mineral partition between soluble and colloidal phases after salt addition was assessed both experimentally and by using computer simulation. Enzymatic coagulation was proceeded at $30^{\circ} \mathrm{C}$. Hydrolysis of $\kappa$-casein was followed by the quantitative determination of caseinomacropeptide released by RP-HPLC, aggregation of para-k-casein micelles was measured through the evolution of backscattering properties of milk and the gel time and gel firming kinetics were determined using a Chymograph (Chr. Hansen, Horsholm, Denmark). The KCl addition did not affect mineral partition. As expected, $\mathrm{CaCl}_{2}$ addi-
\end{abstract}

Received April 20, 2020

Accepted June 26, 2020.

*Corresponding author: Thomas.croguennec@agrocampus-ouest.fr tion mainly increased the CCP content, whereas the addition of $\mathrm{MgCl}_{2}$ mainly increased the bound divalent cations content. The kinetics of $\kappa$-casein hydrolysis was slowed down after $\mathrm{CaCl}_{2}$ and $\mathrm{MgCl}_{2}$ addition, and was negatively correlated with the concentration of divalent cations in the soluble phase of milk. Aggregation and gel firming curves plotted versus the progress of $\kappa$-casein hydrolysis were similar for both $\mathrm{CaCl}_{2^{-}}$and $\mathrm{MgCl}_{2}$-supplemented milk. In view of the dual-binding model for CM assembly, this means that both Ca forms reduce electronegative repulsions between para-micelles by specific charge shielding. Inclusion of $2 \mathrm{Ca}$ forms in structural models for $\mathrm{CM}$ allows a more detailed comprehension of how mineral equilibria affect CM properties.

Key words: calcium, magnesium, mineral partition, casein micelle, enzymatic coagulation

\section{INTRODUCTION}

Caseins are the main protein fraction of milk. In association with large amounts of $\mathrm{Ca}$ and phosphate $(7 \%$ wt/wt on dry basis), they are naturally found superstructured in the form of casein micelle $(\mathbf{C M})$, some roughly spherical particles of $\sim 100 \mathrm{~nm}$, composed of several thousands of casein molecules. The structure of the CM is porous (Bouchoux et al., 2010), with typical hydration value of 2 to $4 \mathrm{~g} \mathrm{H}_{2} \mathrm{O} / \mathrm{g}$ protein (Horne and Lucey, 2017). Despite decades of research, CM structure remains hypothetical, and several structural models are still debated (Schmidt, 1982; Holt, 1992; Horne, 1998). Nonetheless, all models agree that the colloidal calcium phosphate $(\mathbf{C C P})$ is sequestered by the phosphoserine (SEP) residues of caseins in small grain-like structures called nanoclusters. This protein/mineral interaction is a key element of all casein models, as it holds micelle subunits together in the subunit model (Schmidt, 1982), allows the casein polymerization in the calcium phosphate nanocluster model (Holt, 1992) and reduces the strong electrostatic repulsions that promotes and strengthens hydrophobic bonds in the dual-binding 
model (Horne, 1998). It is also admitted that $\kappa$-casein is located on the surface of the CM, forming a protruding "hairy layer." The resulting steric and electrostatic repulsions prevent close approach between $\mathrm{CM}$ and are responsible for their colloidal stability (de Kruif, 1998).

During cheese making, CM destabilization is achieved through milk acidification, coagulant addition or a combination of both, as all modify the state of the $\kappa$-casein layer. During enzymatic coagulation, the added proteolytic enzymes hydrolyze the C-terminal part of $\kappa$-casein, called the caseinomacropeptide (CMP), which decreases repulsions between partially or fully hydrolyzed micelles, called para- $\kappa$-casein micelles. When a sufficient amount of $\kappa$-casein has been hydrolyzed ( $\sim 70 \%$ at the natural $\mathrm{pH}$ of milk), the collisions between para-micelles become effective and they start to aggregate. If the casein volume fraction is sufficiently high, a gel forms when the aggregated material fills the entire initial milk volume. After gelation time, aggregation of more para-micelles or rearrangement of the gel structure leads to an increase of the gel firmness (Horne and Lucey, 2017). Hydrolysis of $\kappa$-casein, aggregation of para-micelles, and gel firming are usually defined as the 3 stages of the enzymatic coagulation. It is noteworthy that these stages overlap during milk coagulation (Choi et al., 2015).

The mineral partition between the soluble phase and $\mathrm{CM}$ is known to strongly influence the enzymatic coagulation of milk. By studying the natural mineral variations in milk, it has been found that milk with high content of colloidal $\mathrm{Ca}$ and colloidal $\mathrm{Mg}$ exhibits better coagulation properties (Malacarne et al., 2014). Addition of $1 \mathrm{mM} \mathrm{CaCl} 2$ in milk has no effect on the $\kappa$-casein hydrolysis but decreases the gel time and increases the rate of development of the gel elastic modulus (Sandra et al., 2012). Choi et al. (2015), by varying the micellar Ca content, either by $\mathrm{pH}$ reduction or by EDTA addition, conclude that a reduction of the colloidal Ca increases repulsion between SEP residues and leads to weaker gels (Choi et al., 2007). Zoon et al. (1988) reported that the positive effects of Ca addition at constant $\mathrm{pH}$ is due to the increase of the $\mathrm{Ca}^{2+}$ activity in the soluble phase. They also reported that at constant $\mathrm{Ca}^{2+}$ activity, a decrease of CCP increases gel time and decreases the elastic modulus of the gel at a fixed time after gelation. The effects of various salt additions on enzymatic coagulation was assessed by Udabage et al. (2001). They concluded that the gel formation was mainly affected by the CCP and casein content in the $\mathrm{CM}$, with a minimal content required for gel formation and an optimal ratio of CCP:casein for gel development. Interestingly, they reported that when these conditions were met, the coagulation properties were governed by the $\mathrm{Ca}^{2+}$ activity in the soluble phase.
However, the precise role of colloidal $\mathrm{Ca}$ and $\mathrm{Ca}^{2+}$ activity is not fully understood. It may come from the consideration that the CCP is the only form of colloidal $\mathrm{Ca}$. Some authors hypothesized that colloidal $\mathrm{Ca}$ exists as nanoclusters of precipitated Ca phosphate, the CCP, and as bound directly to the SEP residues of protein, without inorganic phosphate, sometimes called caseinate calcium or bound calcium (Holt et al., 1986). This $\mathrm{Ca}$ bound to SEP residues (and in minor proportions to aspartic and glutamic acids) was defined as being in equilibrium with $\mathrm{Ca}^{2+}$ in the soluble phase in a simple first-order reaction of complexation. The existence of the bound $\mathrm{Ca}$ is consistent with the work of Aoki et al. (1992) who hypothesized that only clusters of SEP residues interact with CCP. Some free SEP residues (i.e., not interacting with $\mathrm{CCP}$ ) would then exist with a great affinity for divalent cations, such as $\mathrm{Ca}^{2+}$ or $\mathrm{Mg}^{2+}$. Moreover, NMR studies have recently suggested the existence of intra- or inter-Ca bridging between SEP residues of casein monomers without the participation of inorganic phosphate, supporting the idea that some micellar $\mathrm{Ca}$ is directly bound to caseins (Hindmarsh and Watkinson, 2017).

We can wonder if the existence of $2 \mathrm{Ca}$ forms (bound and precipitated) in the $\mathrm{CM}$ is consistent and helpful to understand the effects of mineral equilibria on the enzymatic coagulation. However, any hypothesis based on the existence of 2 forms of colloidal Ca is difficult to demonstrate, as these 2 forms cannot be distinguished by experimental measurements. This can be circumvented by comparing the addition of $\mathrm{MgCl}_{2}$ and $\mathrm{CaCl}_{2}$ to milk. Dimagnesium phosphate is more soluble than $\mathrm{CaHPO}_{4}$ and has a lower degree of saturation in milk soluble phase (Gaucheron, 2005). Thus, upon addition of $\mathrm{MgCl}_{2}$ to milk, $\mathrm{Mg}^{2+}$ is mainly exchanged with $\mathrm{CM}$ in the bound form, whereas upon addition of $\mathrm{CaCl}_{2}$, $\mathrm{Ca}^{2+}$ is exchanged either as bound $\mathrm{Ca}$ or precipitated CPP (Figure 1). Assuming that $\mathrm{Ca}^{2+}$ and $\mathrm{Mg}^{2+}$ have the same binding constants with the SEP residues (Bijl et al., 2019) and that their effects on CM properties are similar, we aimed to compare the addition of $\mathrm{CaCl}_{2}$ and $\mathrm{MgCl}_{2}$ to assess the effect of free cations $\left(\mathrm{Ca}^{2+}\right.$ and $\left.\mathrm{Mg}^{2+}\right)$, bound cations and precipitated CCP on enzymatic coagulation. Additionally, $\mathrm{KCl}$ addition was performed as positive control to differentiate the effect of ionic strength increase from that of specific ions $(\mathrm{Ca}$ and $\mathrm{Mg}$ ) addition.

\section{MATERIALS AND METHODS}

\section{Materials}

A low-heat skim milk powder was prepared from a skim milk supplied by Fromagerie Gillot (Saint-Hilaire- 


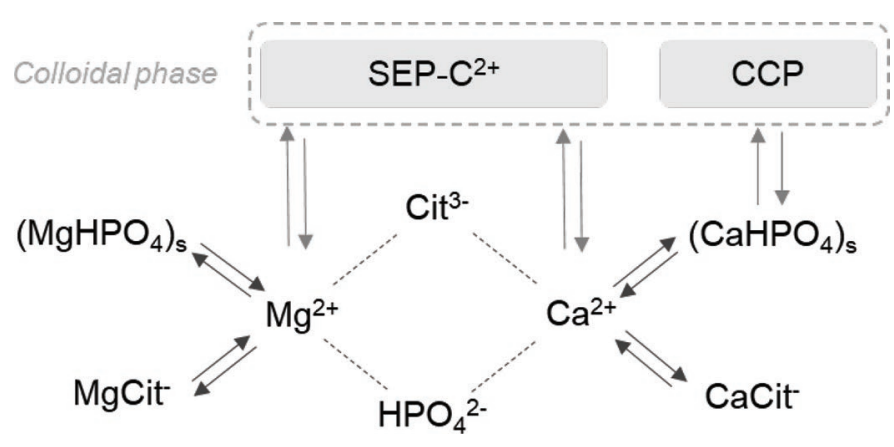

Figure 1. Calcium and $\mathrm{Mg}$ partition between the soluble phase (whey) and colloidal phase (casein micelles) in milk; SEP-C ${ }^{2+}$ represents divalent cations directly bound with phosphoserine residues (without inorganic phosphate), and CCP is the precipitated colloidal calcium phosphate, sequestered by phosphorylated centers of caseins.

de-Briouze, France) and microfiltered through a $1.4-\mu \mathrm{m}$ membrane at $50^{\circ} \mathrm{C}$. The skim milk was concentrated in a 2-stage falling film vacuum evaporator set on the first stage at $64^{\circ} \mathrm{C}$. The concentrated milk temperature was $50^{\circ} \mathrm{C}$ at the outlet of the first stage and $38^{\circ} \mathrm{C}$ at the outlet of the evaporator. Concentrated milk was then spray dried at the semi-industrial drying unit Bionov (Bionov INRA-STLO-Rennes, France). The milk concentrate fed the spray drier at a flow rate of $80 \mathrm{~L} / \mathrm{h}$. The temperatures of inlet and outlet air were $240^{\circ} \mathrm{C}$ and $88^{\circ} \mathrm{C}$, respectively, and the airflow was set at $15 \mathrm{~m} / \mathrm{s}$ to ensure proper drying conditions. A dehumidifier adjusted the inlet air humidity. The temperature of the integrated fluid bed air was set at $75^{\circ} \mathrm{C}$. The $\mathrm{CaCl}_{2} \cdot 2 \mathrm{H}_{2} \mathrm{O}$ and sodium azide were purchased from Sigma-Aldrich (St. Louis, $\mathrm{MO}$ ) and $\mathrm{MgCl}_{2} \cdot 6 \mathrm{H}_{2} \mathrm{O}$ from Merck (Darmstadt, Germany). The $\mathrm{KCl}$ was purchased from PanReac (Lyon, France). The $\mathrm{NaOH}$ and lactic acid were purchased from VWR International (Fontenay-sous-Bois, France). The coagulant used for all experiments was a fermentation-produced chamel chymosine (CHY-MAX Supreme 1,000 international milk clotting units $/ \mathrm{mL}$, Chr. Hansen, Horsholm, Denmark). A protease from Rhizomucor miehei (MICROLANT Supreme 200 international milk clotting units/mL, Chr. Hansen) was also tested when specified.

\section{Sample Preparation}

Milk was reconstituted at $110 \mathrm{~g} / \mathrm{kg}$ using the powder described hereabove in ultrapure water. Sodium azide was added at a final concentration of $0.2 \mathrm{~g} / \mathrm{L}$ and the milk was stirred during $2 \mathrm{~h}$ at room temperature under magnetic stirring. The milk was aliquoted and $\mathrm{CaCl}_{2}$, $\mathrm{MgCl}_{2}$, or $\mathrm{KCl}$ were added at $10 \mathrm{~m} M$ from $0.4 M$ stock solutions. Then, milk samples were left $30 \mathrm{~min}$ at $30^{\circ} \mathrm{C}$ and their pH was adjusted to 6.60 with $0.1 \mathrm{M} \mathrm{NaOH}$ or $10 \mathrm{~mL} / \mathrm{L}$ lactic acid and then left overnight at room temperature. After $12 \mathrm{~h}$, the $\mathrm{pH}$ was re-adjusted and the volume completed with ultrapure water to reach 100 $\mathrm{g} / \mathrm{L}$ of skim milk powder ( $\sim 35 \mathrm{~g} / \mathrm{L}$ proteins). Samples were finally left for equilibration at least $30 \mathrm{~min}$ at $30^{\circ} \mathrm{C}$ before any analysis. All milk samples had a final $\mathrm{pH}$ of $6.60 \pm 0.04$.

\section{Quantification of Mineral Concentrations}

Total $\mathrm{Ca}$ and total $\mathrm{Mg}$ were quantified directly from milk samples. To determine total phosphate concentration, milk samples were diluted (1:2) in ultrapure water, $\mathrm{pH}$ was slowly decreased to $\sim 3.6$ and the supernatant from centrifugation $(6,800 \times g$ during $15 \mathrm{~min})$ was collected for analysis.

To determine soluble minerals $(\mathrm{Ca}, \mathrm{Mg}$, and phosphate), milk samples were ultracentrifuged at 100,000 $\times g$ (Sorvall, Discovery 90SE, Hitachi, USA) with a $\mathrm{T}-865$ rotor for $1 \mathrm{~h}$ at $23^{\circ} \mathrm{C}$. The supernatant was carefully collected and filtered with VivaSpin-10 kDa before analysis. Concentrations obtained for the supernatant were multiplied by 0.976 to take into account the excluded volume fraction (Gaucheron, 2004).

Phosphate concentrations were determined by ionic chromatography coupled with suppressed conductivity detection (Dionex DX 500, Dionex, Voisin-le-Bretonneux, France), according to Gaucheron et al. (1996). Calcium and $\mathrm{Mg}$ concentrations were determined with an atomic absorption spectrometer (Varian 220FS Spectr AA, Les Ulis, France) according to Le Graët and Brulé (1993).

Colloidal Ca, colloidal Mg, and colloidal phosphate concentrations were obtained by the difference between total and soluble concentrations.

The $\mathrm{Ca}^{2+}$ concentration was measured in milk samples at $30^{\circ} \mathrm{C}$ using an ionometer SevenMulti S50 (Mettler Toledo, Schwerzenvach, Switzerland) equipped with a reference electrode Inlab 302 and a Ca-selective electrode DX240- $\mathrm{Ca}^{2+}$. Calibration standards of Ca were prepared using $\mathrm{CaCl}_{2}$ at final concentration ranging from 0.1 to $20 \mathrm{mM}$. Ionic strength of each standard was adjusted at $\sim 70 \mathrm{~m} M$ with corresponding $\mathrm{KCl}$ addition.

Mineral partition was also modeled using the software MilkSalts GLM (Mekmene et al., 2009) from the total mineral concentrations determined experimentally.

\section{Zeta Potential Measurement}

The zeta potential of CM was measured by electrophoretic light scattering using a Zetasizer Nano-ZS (Malvern Instruments, Malvern, UK). The analysis 
was performed at room temperature $\left(\sim 20^{\circ} \mathrm{C}\right)$ and the applied voltage was $50 \mathrm{~V}$. Milk samples were diluted $(1: 100)$ in their own supernatant of ultracentrifugation $\left(100,000 \times g\right.$ for $1 \mathrm{~h}$ at $\left.23^{\circ} \mathrm{C}\right)$ just prior measurement.

\section{Kinetics of Caseinomacropeptide Release}

The kinetics of $\kappa$-casein hydrolysis was followed by measuring the release of the CMP over time, according to a modified version of the protocol used by Thomä et al. (2006). Milk aliquots of $10 \mathrm{~mL}$ were incubated with coagulant $\left(30^{\circ} \mathrm{C} ; 5,000\right.$ international milk clotting units $/ 100 \mathrm{~L}$ of milk) and the reaction was stopped at different times with $20 \mathrm{~g} / \mathrm{L}$ trichloroacetic acid. Samples were left at room temperature for 15 min to allow precipitation of proteins. After centrifugation at 6,800 $\times g$ for $10 \mathrm{~min}$ at room temperature, the supernatant was diluted in solvent A and filtered through a $0.45-\mu \mathrm{m}$ syringe filter. The CMP was quantified by RP-HPLC using Dionex UltiMate 3000 HPLC System (Thermo Fisher, Dreieich, Germany), equipped with a detector VWD3400RS (Thermo Fisher) and a PLRP-S $300 \AA$ column $(8 \mu \mathrm{m}, 150 \times 2 \mathrm{~mm}$, Agilent Technologies, Santa Clara, CA). A gradient of solvent A consisting of $0.1 \%$ ( $\mathrm{vol} / \mathrm{vol}$ ) trifluoroacetic acid dissolved in water and solvent B consisting of $0.1 \%$ trifluoroacetic acid dissolved in acetonitrile was applied. The gradient started with a plateau of 2 min at $16 \%$ of solvent B and was successively increased in solvent B to $32 \%$ in 3 min, $48 \%$ in $15 \mathrm{~min}$, and finally $80 \%$ in $4 \mathrm{~min}$. Analyses were performed at $40^{\circ} \mathrm{C}$ and at a constant flow rate of $0.2 \mathrm{~mL} / \mathrm{min}$. Peak detection was done at $214 \mathrm{~nm}$. The kinetics of CMP release was constructed as follows: during preliminary work, the CMP chromatographic peak area at complete $\kappa$-casein hydrolysis was determined, the relative amount of CMP released at a given time was then calculated as the ratio between the obtained chromatographic peak area, and the chromatographic peak area at complete hydrolysis.

\section{Kinetics of Aggregation of Hydrolyzed Micelles}

Aggregation kinetics of para-micelles were measured using a light backscattering technique, as reviewed by Payne and Castillo (2007). In the present work, a Turbiscan LAB (Turbiscan Laboratory Formulation, Ramonville St. Agne, France) was used as light backscattering sensor. The device was equipped with a diode emitting at $880 \mathrm{~nm}$ and an optical sensor placed at $45^{\circ}$ from the emitting diode. Samples were analyzed in disposable glass vats, in the temperature-controlled chamber of the device, set at $30^{\circ} \mathrm{C}$.
Aliquots of milk were preheated in a water bath at $30^{\circ} \mathrm{C}$, and the coagulant was added (5,000 international milk clotting units/100 L of milk). Milk was gently stirred by shaking by hand and $\sim 20 \mathrm{~mL}$ of rennetedmilk were quickly loaded into the glass vat. Analysis was performed during 25 min at 1 point/25 s. The Turbiscan $\mathrm{LAB}$ allows the determination of the backscattered flux of the sample, relative to a standard backscattered flux. To obtain a signal comparable to the light backscatter ratio as described by Payne and Castillo (2007), which aims to normalize the backscatter signal of the sample by its initial values, the initial value of the backscatter flux was subtracted to the value of the flux at a given time.

A typical signal collected during milk coagulation is presented on Figure 2. After the latent period where only $\kappa$-casein hydrolysis occurs, the increase of backscattered flux was assigned to increase of particle size (i.e., para-micelles aggregation) by Castillo et al. (2003). They assumed that after the inflection point of the curve, the increase of backscattered signal was due to both aggregation of para-micelle and curd firming (i.e., cross-linking in the preliminary network), even if no elastic modulus can be measured at these times (Castillo et al., 2003). They also assumed that aggregation was the dominant process between the inflection point and the shoulder of the curve. Thus, we considered that the first increase of backscattering flux until the shoulder was essentially due to aggregation of para-micelles. The shoulder, more visible at low temperature and low protein concentration, traduces the overlapping between aggregation and curd firming (Castillo et al., 2003). The aggregation time (i.e., when para-micelles start to aggregate) was arbitrary defined as the crosslink point between abscissa axis and the tangent at the inflection point.

\section{Kinetics of Gel Firming}

The sol-gel transition and gel firming were followed using a Chymograph (Chr. Hansen, Horsholm, Denmark). The device is based on the principle of the Formagraph (McMahon and Brown, 1982). Renneted milk is introduced in a temperature-controlled block containing 8 wells. A free pendulum is immersed in each milk sample, and the block is set in a small translation oscillating movement. During gelation, the pendulum is progressively set in motion, and its movement is measured by an optical sensor and numerically recorded with a computer. The amplitude of the pendulum traduces the gel firmness (arbitrary unit). Aliquots of milk samples were preheated in a water bath at $30^{\circ} \mathrm{C}$ and coagulant was added (5,000 international milk clotting units/100 
L of milk). Milk was gently stirred by shaking with hand and $10 \mathrm{~mL}$ were quickly loaded in each well. The gel firmness was measured every $15 \mathrm{~s}$ during at least 60 min after coagulant addition. During preliminary work, simultaneous analysis of milk with a Chymograph and a rheometer where conducted (Figure 3). Rheological measurements were carried using DHR-2 instrument (TA Instruments, Guyancourt, France) equipped with a Couette geometry (inner and outer radii $=28.0$ and 30.4 $\mathrm{mm}$ ) at a frequency of $0.1 \mathrm{~Hz}$ and at $0.1 \%$ strain. It was found that the gel time observed with the rheometer $\left(\mathrm{G}^{\prime}>0.1 \mathrm{~Pa}\right.$ and $\left.\mathrm{G}^{\prime}>\mathrm{G}^{\prime \prime}\right)$ corresponded to a firmness of 0.3 with the Chymograph. Thus, the gel time was defined when gel firmness crossed the value 0.3. The gel firmness after coagulant addition determined with the Chymograph was correlated with the elastic modulus determined using the DHR-2 rheometer (Figure 3). Chymograph was selected for this study because it is well suited to characterize the gel time and the early stages of curd firming and it allows the simultaneous analyze 8 samples and thus to obtain a great number of repetitions without extensive milk storage.

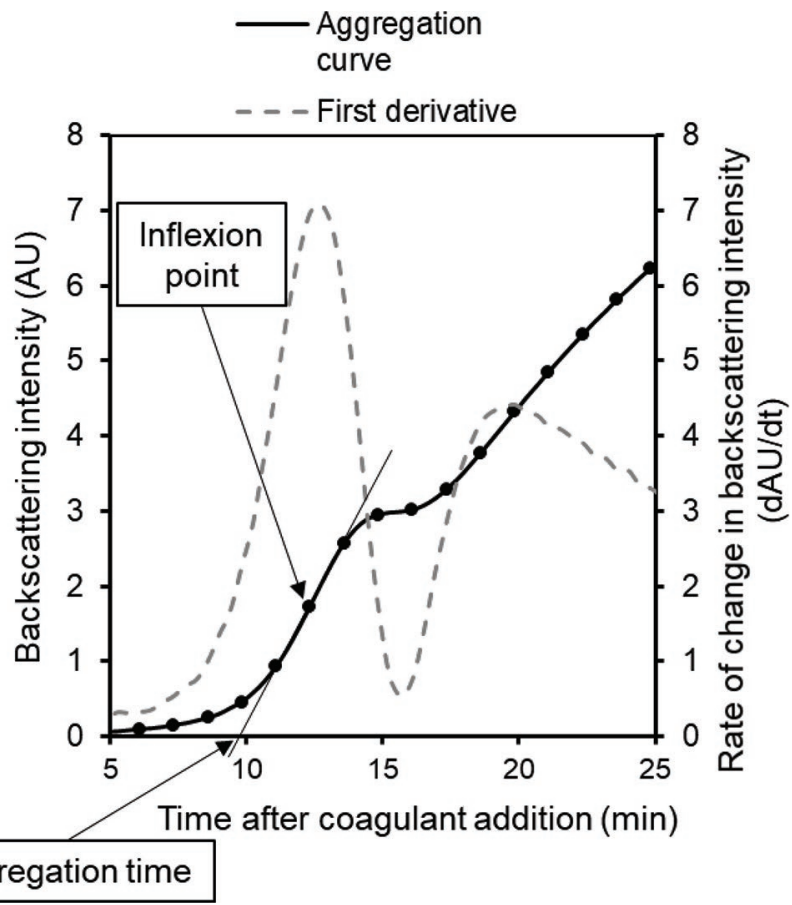

Figure 2. Example of signal collected from the Turbiscan LAB (Turbiscan Laboratory Formulation, Ramonville St. Agne, France) during the enzymatic coagulation of milk (3.5\% proteins at $\mathrm{pH} 6.6$ and $30^{\circ} \mathrm{C}$; the coagulant strength was 5,000 international milk clotting units $/ \mathrm{mL}$ ). The first increase of backscattering intensity was attributed to the increase of the diameter of particles during aggregation of para-micelles. $\mathrm{AU}=$ arbitrary units; $\mathrm{dAU} / \mathrm{dt}=$ time derivative of the arbitrary unit.

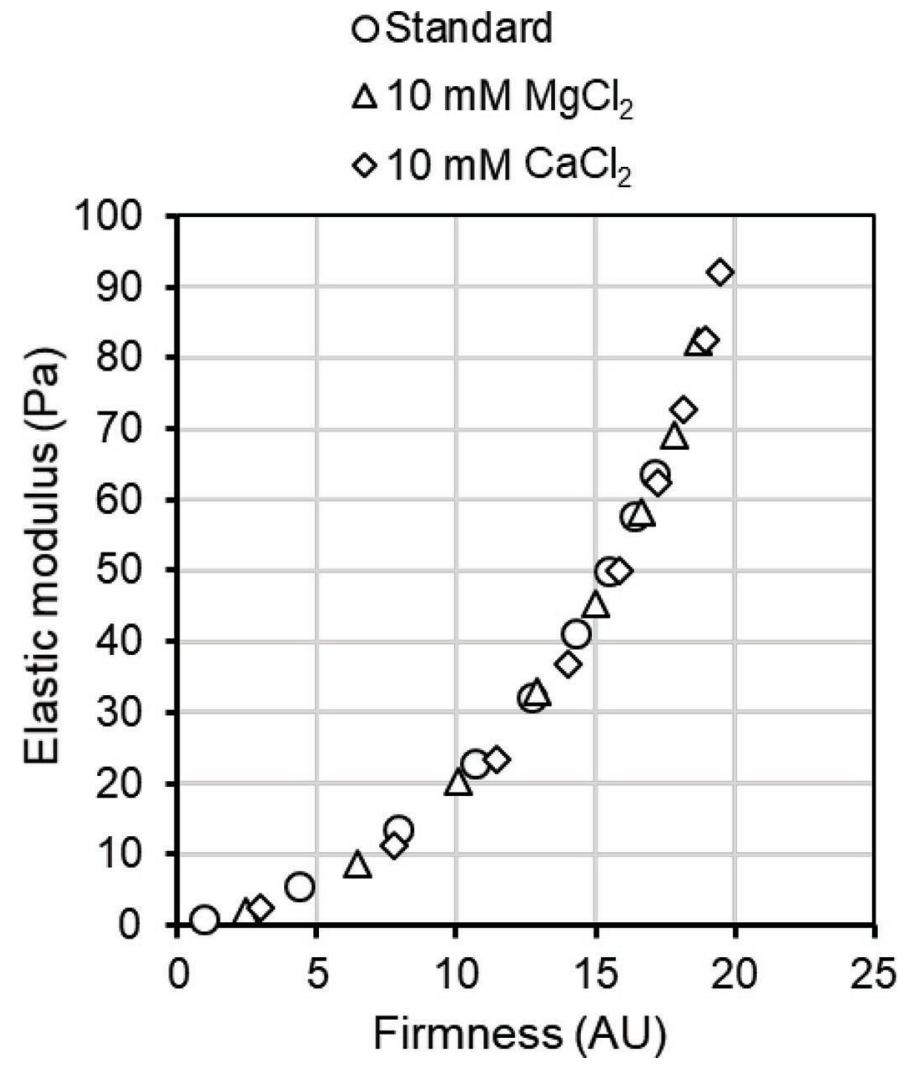

Figure 3. Comparison of Chymograph (Chr. Hansen, Horsholm, Denmark) and rheology to follow the kinetics of gel firming after coagulant addition. Coagulation of milk (3.5\% proteins) was proceeded at $30^{\circ} \mathrm{C}, \mathrm{pH}=6.6$, and the coagulant strength was 5,000 international milk clotting units $/ \mathrm{mL}$. $\mathrm{AU}=$ arbitrary units.

\section{Statistical Analysis}

The whole experiment was repeated twice from 2 different milk preparations. One more set of repetitions was done for Chymograph analysis from a third milk preparation. Analysis of variance test and StudentNewman-Keuls tests were used for multiple mean comparison (risk $\alpha=0.05$ ). If ANOVA conditions were not valid, a Kruskal-Wallis test followed by Dunn test were used. All calculations were done using R (R Development Core Team, 2010, R Foundation for Statistical Computing, Vienna, Austria. http://www.R-project .org).

\section{RESULTS}

\section{Effect of Added Salts on Mineral Partition and Casein Micelle Zeta Potential}

Effect of $10 \mathrm{~m} M \mathrm{CaCl}_{2}$ and $10 \mathrm{~m} M \mathrm{MgCl}_{2}$ addition on mineral partition was determined experimentally (Ta- 
Table 1. Mineral concentrations $(\mathrm{m} M)$ of milk samples determined experimentally after salt additions

\begin{tabular}{|c|c|c|c|c|c|}
\hline Phase & $\begin{array}{l}\text { Salt } \\
\text { addition }\end{array}$ & $\begin{array}{l}\text { Standard } \\
\text { (none) }\end{array}$ & $\begin{array}{c}10 \mathrm{~m} M \\
\mathrm{KCl}\end{array}$ & $\begin{array}{l}10 \mathrm{mM} \\
\mathrm{MgCl}_{2}\end{array}$ & $\begin{array}{c}10 \mathrm{~m} M \\
\mathrm{CaCl}_{2}\end{array}$ \\
\hline \multirow[t]{4}{*}{ Soluble } & Phosphate & $10.4 \pm 0.2^{\mathrm{a}}$ & $10.4 \pm 0.2^{\mathrm{a}}$ & $8.1 \pm 0.3^{\mathrm{b}}$ & $6.1 \pm 0.2^{\mathrm{c}}$ \\
\hline & $\mathrm{Ca}$ & $8.2 \pm 0.1^{\mathrm{a}}$ & $8.2 \pm 0.4^{\mathrm{a}}$ & $6.3 \pm 0.1^{\mathrm{b}}$ & $10.0 \pm 0.3^{\mathrm{c}}$ \\
\hline & $\mathrm{Ca}^{2+}$ & $1.3 \pm 0.2^{\mathrm{a}}$ & $1.3 \pm 0.3^{\mathrm{a}}$ & $1.9 \pm 0.4^{\mathrm{b}}$ & $2.6 \pm 0.5^{\mathrm{c}}$ \\
\hline & $\mathrm{Mg}$ & $2.9 \pm 0.1^{\mathrm{a}}$ & $2.9 \pm 0.1^{\mathrm{a}}$ & $9.2 \pm 0.4^{\mathrm{b}}$ & $2.7 \pm 0.1^{\mathrm{a}}$ \\
\hline \multirow[t]{3}{*}{ Colloidal } & Phosphate & $10.4 \pm 0.6^{\mathrm{a}}$ & $11.0 \pm 0.3^{\mathrm{a}}$ & $13.2 \pm 0.4^{\mathrm{b}}$ & $14.9 \pm 0.6^{\mathrm{c}}$ \\
\hline & $\mathrm{Ca}$ & $25.0 \pm 1.3^{\mathrm{a}}$ & $25.0 \pm 1.3^{\mathrm{a}}$ & $27.0 \pm 1.2^{\mathrm{b}}$ & $32.7 \pm 0.9^{\mathrm{c}}$ \\
\hline & $\mathrm{Mg}$ & $1.9 \pm 0.1^{\mathrm{a}}$ & $1.9 \pm 0.1^{\mathrm{a}}$ & $5.5 \pm 0.4^{\mathrm{b}}$ & $2.2 \pm 0.4^{\mathrm{a}}$ \\
\hline
\end{tabular}

${ }^{\mathrm{a}-\mathrm{c}}$ Means $\pm \mathrm{SD}$ with different superscripts within a row differ $(P<0.05)$.

ble 1) and using a model of mineral equilibria designed for milk (Table 2; Mekmene et al., 2009). Predicted concentrations in the soluble and colloidal phases were conformed to experimental determinations. Small differences can be explained by the possible differences between the milk system used here and the one used for the software development (heat treatment, phenotype of caseins).

Experimentally, addition of $10 \mathrm{mM} \mathrm{CaCl} \mathrm{Cl}_{2}$ increased colloidal Ca $(+7.7 \mathrm{mM})$, colloidal phosphate $(+4.5$ $\mathrm{m} M)$, and $\mathrm{Ca}^{2+}(+1.3 \mathrm{~m} M$; Table 1$)$. Addition of 10 $\mathrm{m} M \mathrm{MgCl}_{2}$ increased colloidal $\mathrm{Mg}(+3.6 \mathrm{~m} M)$ but also increased colloidal $\mathrm{Ca}(+2.0 \mathrm{mM})$ and colloidal phosphate $(+2.8 \mathrm{mM})$. Finally, $77 \%$ of the added $\mathrm{Ca}$ and $36 \%$ of the added $\mathrm{Mg}$ were exchanged with the colloidal phase after addition of $10 \mathrm{mM} \mathrm{CaCl} 2$ and 10 $\mathrm{m} M \mathrm{MgCl}_{2}$, respectively (Table 1 ).

Calculated concentrations of colloidal Ca $(+8.0 \mathrm{mM})$, colloidal phosphate $(+3.8 \mathrm{mM})$, and $\mathrm{Ca}^{2+}(+1.3 \mathrm{mM})$ after addition of $10 \mathrm{mM} \mathrm{CaCl} \mathrm{Cl}_{2}$ were in agreement with experimental results (Table 2). After $\mathrm{MgCl}_{2}$ addition, calculated concentration of colloidal $\mathrm{Mg}(+2.6 \mathrm{mM})$ was lower than the experimental value; colloidal $\mathrm{Ca}(+2.0$ $\mathrm{m} M)$ and colloidal phosphate $(+1.6 \mathrm{mM})$ were also increased, as observed in experimental data. In the model system, $80 \%$ of the added $\mathrm{Ca}$ and $26 \%$ of the added $\mathrm{Mg}$ were exchanged with the colloidal phase after addition of $10 \mathrm{mM} \mathrm{CaCl}$ and $10 \mathrm{mM} \mathrm{MgCl}$, respectively.

The software also returns milk ionic strength, which was 63.3, 71.9 and $66.0 \mathrm{~m} M$ for the standard (no salt addition), $\mathrm{MgCl}_{2^{-}}$and $\mathrm{CaCl}_{2}$-supplemented milks, respectively. To assess the effect of the ionic strength increase, which was notable after $\mathrm{MgCl}_{2}$ addition, a positive control with $10 \mathrm{~m} M$ added $\mathrm{KCl}$ was introduced (calculated ionic strength $\sim 73.3 \mathrm{mM}$ ). The increase of ionic strength by addition of $10 \mathrm{mM} \mathrm{KCl}$ did not significantly affect mineral partitioning between colloidal and soluble phase in comparison with the standard milk (Table 1 and Table 2).

For the calculation of micellar concentrations, the software considers 2 mineral forms: a precipitated CCP (the so-called nanoclusters) and cations $\left(\mathrm{Ca}^{2+}\right.$ and $\mathrm{Mg}^{2+}$ ) directly bound to SEP residues (Table 2). It allows a more detailed analysis of how added $\mathrm{Ca}$ and added $\mathrm{Mg}$ are exchanged with $\mathrm{CM}$.

The increase of colloidal $\mathrm{Ca}$ after $10 \mathrm{mM} \mathrm{CaCl}_{2}$ addition was mainly due to the increase of CCP $(+7.0$ $\mathrm{mM}$; Table 2). This addition simultaneously increased Ca bound to SEP $(+0.9 \mathrm{mM})$. The addition of $10 \mathrm{mM}$ $\mathrm{MgCl}_{2}$ increased $\mathrm{Mg}$ bound to SEP $(+2.6 \mathrm{mM})$, de-

Table 2. Mineral concentrations $(\mathrm{m} M)$ calculated from the software MilkSalts GLM (Mekmene et al., 2009) ${ }^{1}$

\begin{tabular}{|c|c|c|c|c|c|}
\hline Phase & $\begin{array}{l}\text { Salt } \\
\text { addition }\end{array}$ & $\begin{array}{c}\text { Standard } \\
\text { (none) }\end{array}$ & $\begin{array}{c}10 \mathrm{~m} M \\
\mathrm{KCl}\end{array}$ & $\begin{array}{l}10 \mathrm{~m} M \\
\mathrm{MgCl}_{2}\end{array}$ & $\begin{array}{c}10 \mathrm{mM}^{M} \\
\mathrm{CaCl}_{2}\end{array}$ \\
\hline \multirow[t]{5}{*}{ Soluble } & Phosphate & 9.9 & 10.0 & 8.3 & 6.1 \\
\hline & $\mathrm{Ca}$ & 8.9 & 9.1 & 6.9 & 11.0 \\
\hline & $\mathrm{Ca}^{2+}$ & 1.7 & 1.9 & 2.6 & 3.0 \\
\hline & $\mathrm{Mg}$ & 3.1 & 3.1 & 10.5 & 3.1 \\
\hline & $\mathrm{Mg}^{2+}$ & 0.4 & 0.5 & 3.0 & 0.6 \\
\hline \multirow[t]{6}{*}{ Colloidal } & Phosphate & 10.7 & 10.6 & 12.3 & 14.5 \\
\hline & $\mathrm{Ca}$ & 24.3 & 24.1 & 26.3 & 32.3 \\
\hline & $\mathrm{CCP}$ & 20.3 & 20.2 & 23.3 & 27.3 \\
\hline & SEP-Ca ${ }^{2+}$ & 4.0 & 4.0 & 3.1 & 4.9 \\
\hline & $\mathrm{Mg}$ & 1.7 & 1.7 & 4.3 & 1.7 \\
\hline & SEP-Mg ${ }^{2+}$ & 1.0 & 1.0 & 3.6 & 1.0 \\
\hline
\end{tabular}

${ }^{1} \mathrm{CCP}$ represents the Ca contained in the precipitated colloidal Ca phosphate; SEP-Ca ${ }^{2+}$ and SEP- $\mathrm{Mg}^{2+}$ represent $\mathrm{Ca}$ and $\mathrm{Mg}$ bound with phosphoserine residues. 


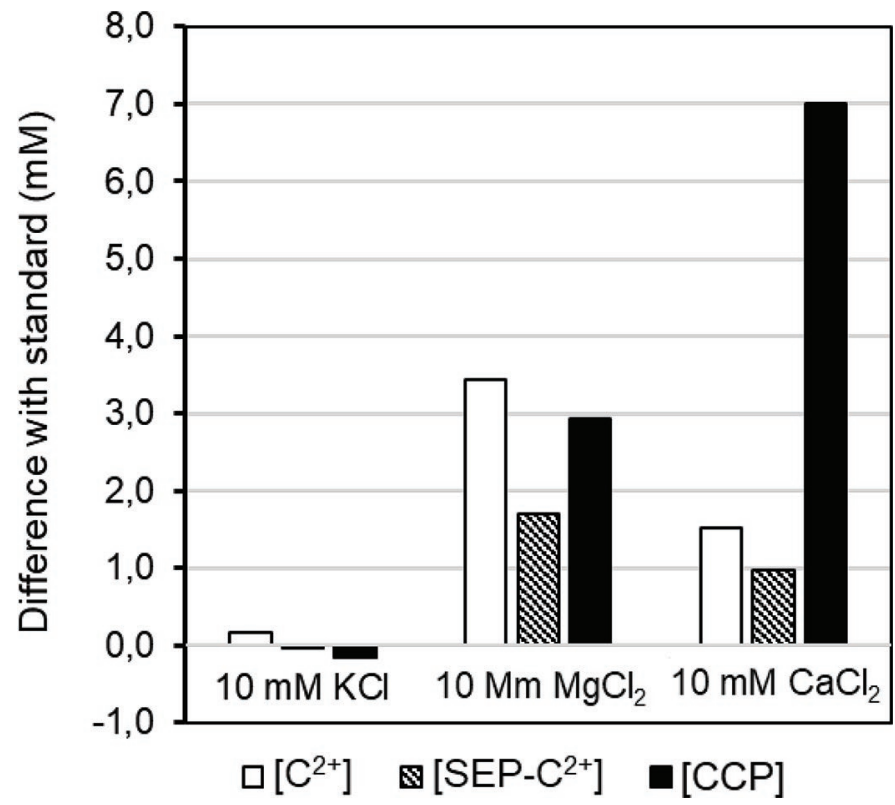

Figure 4. Effects of $\mathrm{KCl}, \mathrm{MgCl}_{2}$, or $\mathrm{CaCl}_{2}(10 \mathrm{mM})$ addition on the cationic content of the soluble phase $\left(\mathrm{C}^{2+}\right)$, the concentration of cations bound to phosphoserines (SEP-C ${ }^{2+}$ ), and the concentration of calcium contained into the precipitated calcium phosphate (CCP). Displayed values are the differences with the standard value. Concentrations of SEP-C ${ }^{2+}$ and CCP were calculated using the software MilkSalts GLM (Mekmene et al., 2009) for a milk at pH 6.6. The total ion concentrations were determined experimentally; $\mathrm{Ca}^{2+}$ and $\mathrm{Mg}^{2+}$ are the only cations considered here.

creased some Ca bound to SEP $(-0.9 \mathrm{mM})$ and also increased CCP $(+3.0 \mathrm{mM})$.

Thus, both $\mathrm{CaCl}_{2}$ and $\mathrm{MgCl}_{2}$ addition increased the concentration of CCP and the concentration of cations bound to SEP. However, the added Mg was exchanged with CM mainly through the bound form whereas most of the added $\mathrm{Ca}$ precipitated with phosphate and increased the precipitated form. These effects are summarized on Figure 4, which shows the differences of concentration with standard of free divalent cations $\left(\mathrm{Ca}^{2+}\right.$ and $\left.\mathrm{Mg}^{2+}\right)$ in the soluble phase $\left(\mathrm{C}^{2+}\right)$, cations bound to SEP (SEP-C ${ }^{2+}$ ) and Ca contained into precipitated CCP (CCP).

All salt additions reduced the zeta potential of $\mathrm{CM}$ in comparison to the standard (Figure 5). However, no statistical difference was found between $\mathrm{MgCl}_{2^{-}}, \mathrm{CaCl}_{2^{-}}$ and KCl-supplemented milk samples.

\section{Enzymatic Hydrolysis}

Kinetics of CMP release were not different between standard and KCl-supplemented milk but slightly slowed down after $10 \mathrm{mM} \mathrm{CaCl}{ }_{2}$ addition (Figure 6). Addition of $10 \mathrm{mM} \mathrm{MgCl} 2$ hindered the enzymatic reaction. The kinetics of hydrolysis were also assessed with another coagulant, a mucorpepsin from Rhizomucor miehi (inset on Figure 6). With this coagulant, the kinetics of the standard and $\mathrm{CaCl}_{2}$-supplemented milk were identical and the kinetics of $\mathrm{MgCl}_{2}$-supplemented milk were only slightly slowed down.

For each sample, the kinetics of hydrolysis were fitted with a mathematical model of the form:

$$
x=100\left(1-e^{-\tau t}\right),
$$

where $x$ is the percentage of liberated CMP (or the percentage of hydrolysis), $t$ is the time after coagulant addition, and $\tau$ is a constant.

In Equation 1, the term $e^{-\tau t}$ traduces the substrate ( $\kappa$-casein) loss assuming a first-order reaction. The modelized curves are displayed on Figure 6.

\section{Kinetics of Aggregation and Gel Firming}

Aggregation kinetics of para-micelles in milk samples after coagulant addition are shown in Figure 7A. From these curves, the aggregation time (time when paramicelles start to aggregate) and the maximum rate of aggregation (maximum of the first derivative of the first increase in backscattering signal) were calculated

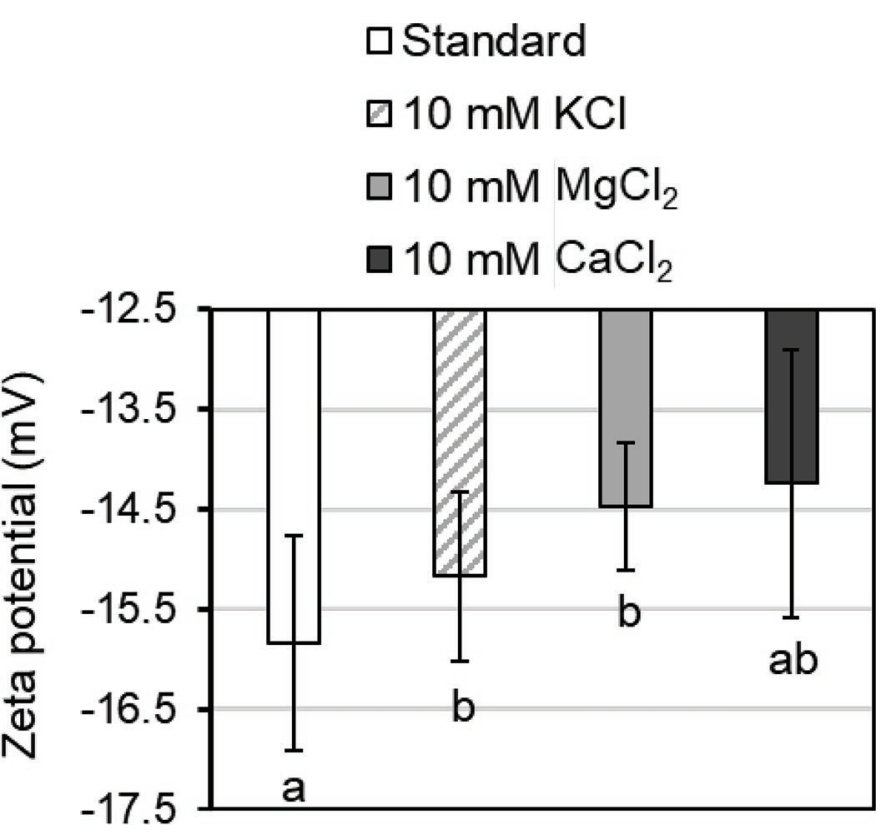

Figure 5. Zeta potential $(\mathrm{mV})$ of casein micelles. Milk samples (3.5\% proteins) were diluted (1:100) in their own supernatant of ultracentrifugation $(\mathrm{pH}=6.6)$ and the measurement was done at room temperature. Mean of 12 repetitions over 2 independent sample preparations. Error bars indicate SD. Letters below error bars denote the group that showed significant difference with the other group $(P<$ $0.05)$. 
○ Standard

$\square 10 \mathrm{mM} \mathrm{KCl}$

$\triangle 10 \mathrm{mM} \mathrm{MgCl}{ }_{2}$

$\diamond 10 \mathrm{mM} \mathrm{CaCl}_{2}$

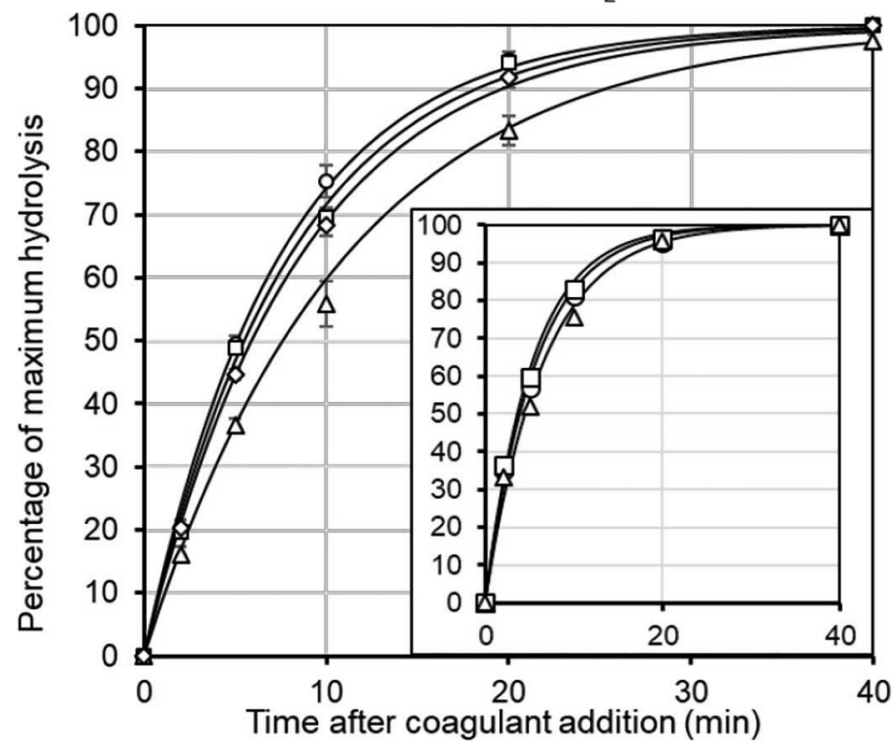

Figure 6. Caseinomacropeptide (CMP) release as a function of the time after coagulant addition (5,000 international milk clotting units/ $\mathrm{mL})$. Milk samples (3.5\% proteins) at $\mathrm{pH} 6.6$ were incubated with the coagulant at $30^{\circ} \mathrm{C}$ and the reaction was stopped by addition of trichloroacetic acid. Maximum amount of CMP detected was defined as $100 \%$. Displayed lines are the data fitted according to Equation 1. Mean of 3 repetitions for standard, $\mathrm{CaCl}_{2}(10 \mathrm{mM})$-supplemented and $\mathrm{MgCl}_{2}(10 \mathrm{mM})$-supplemented milks, and 2 repetitions for the milk with $\mathrm{KCl}(10 \mathrm{mM})$ addition. The inset represents the kinetics of CMP release for the same samples using mucorpepsin as coagulant (no repetition). Error bars indicate SD.

(Table 3). The kinetics of gel firming of milk samples are displayed on Figure 7B. From the gel firming curve, the gel time and the maximum gel firming rate (maximum of the first derivative of the curve) were determined (Table 3).

Addition of $10 \mathrm{mM} \mathrm{CaCl}_{2}$ decreased the gel time and increased both the aggregation and gel firming rates (Table 3 and Figure 7). However, aggregation time of the $\mathrm{CaCl}_{2}$-supplemented milk and of the standard milk were not significantly different. Addition of $10 \mathrm{mM}$ $\mathrm{MgCl}_{2}$ increased both aggregation and gel times. Aggregation rate was not significantly different from the standard but had a tendency to increase. The maximum gel firming rate was also not different from the standard. However, after the maximum gel firming rate, firmness of $\mathrm{MgCl}_{2}$-supplemented milk kept increasing greatly, giving rise to a particular coagulation behavior (Figure 7B). Despite a longer gel time, gel firming curve of $\mathrm{MgCl}_{2}$-supplemented milk progressively reached the curve of the $\mathrm{CaCl}_{2}$-supplemented milk.

\section{o Standard}

$\square 10 \mathrm{mM} \mathrm{KCl}$
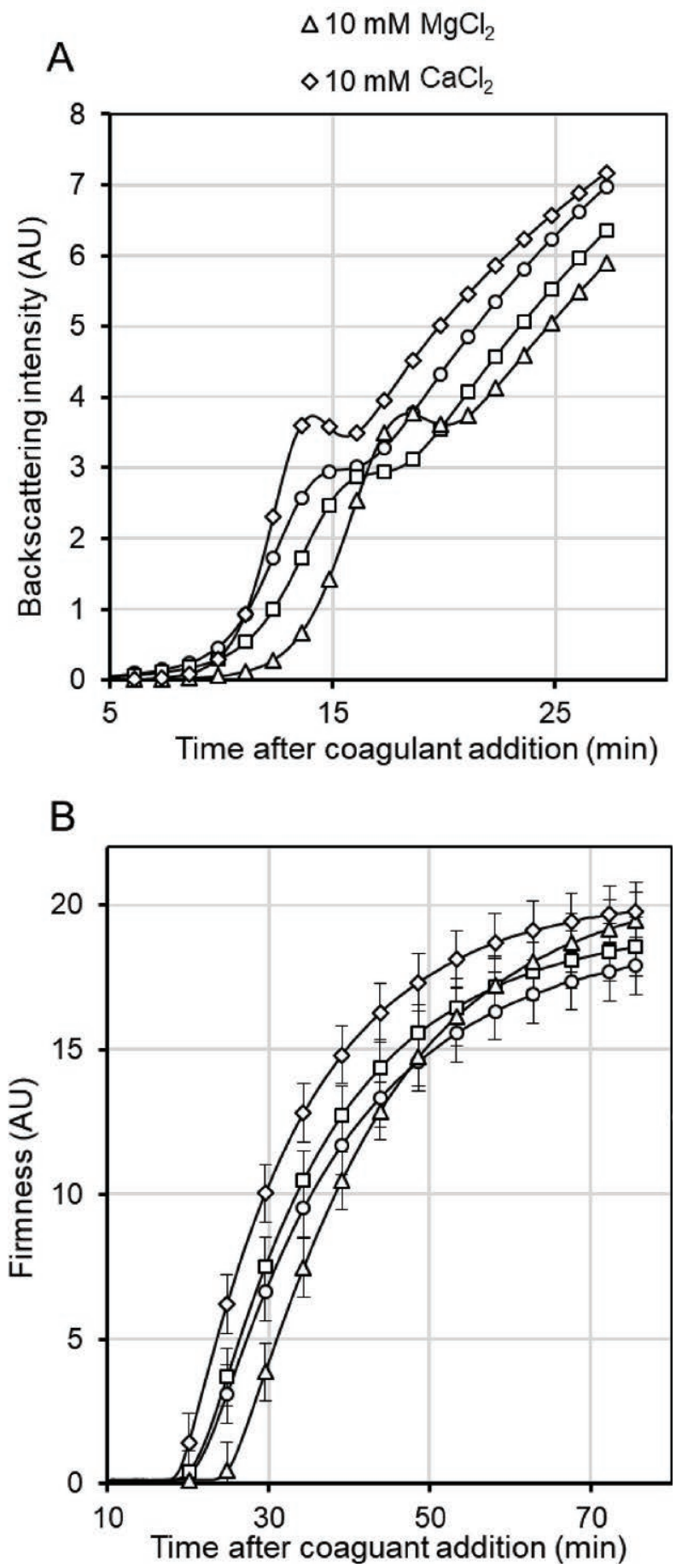

Figure 7. Aggregation kinetics measured with the Turbiscan LAB (Turbiscan Laboratory Formulation, Ramonville St. Agne, France); example of one set of repetition (A) and gel firming kinetics measured with the Chymograph (Chr. Hansen, Horsholm, Denmark). Mean of 6 repetitions over 2 sample preparations (B). Low-heat skim milk powder was reconstituted at $3.5 \%$ of proteins. Coagulation was proceeded at $30^{\circ} \mathrm{C}, \mathrm{pH}=6.6$, and the coagulant strength was 5,000 international milk clotting units $/ \mathrm{mL}$. AU = arbitrary units. 
Table 3. Coagulation indicators extracted from aggregation and coagulation curves ${ }^{1}$

\begin{tabular}{|c|c|c|c|c|}
\hline Item & Standard & $10 \mathrm{~m} M \mathrm{KCl}$ & $10 \mathrm{mM} \mathrm{MgCl}{ }_{2}$ & $10 \mathrm{~m} M \mathrm{CaCl}_{2}$ \\
\hline Maximum rate of aggregation (AU/min) & $6.3 \pm 0.7^{\mathrm{a}}$ & $6.1 \pm 0.5^{\mathrm{a}}$ & $8.3 \pm 0.8^{\mathrm{a}}$ & $10.9 \pm 1.3^{\mathrm{b}}$ \\
\hline
\end{tabular}

${ }^{\mathrm{a}-\mathrm{c}}$ Means $\pm \mathrm{SD}$ with different superscripts within a row differ $(P<0.05)$.

${ }^{1} \mathrm{AU}=$ arbitrary units.

Addition of $10 \mathrm{mM} \mathrm{KCl}$ had no effects on both aggregation and gel firming steps in comparison to the standard milk (Figure 7 and Table 3). Indeed, all coagulation indicators were not significantly different (Table 3).

Aggregation and gel firming curves were also represented versus the percentage of $\kappa$-casein hydrolysis (Figure 8). Using this representation, the aggregation and gel firming curves of $\mathrm{CaCl}_{2}$ and $\mathrm{MgCl}_{2}$-supplemented milk perfectly overlapped. It means that both samples had similar kinetics of aggregation and gel firming assuming that hydrolysis kinetics were similar. These milks started to gel at a lower extent of $\kappa$-casein hydrolysis than the KCl-supplemented milk and standard milk. In the same way, the aggregation curve of standard milk and $\mathrm{KCl}$-supplemented milk overlapped (Figure 8A). However, the KCl-supplemented milk gave rise to a firmer gel than the standard milk for a given percentage of $\kappa$-casein hydrolysis (Figure $8 \mathrm{~B}$ ).

\section{DISCUSSION}

In this work, addition of $\mathrm{Ca}$ (through $\mathrm{CaCl}_{2}$ addition) and $\mathrm{Mg}$ (through $\mathrm{MgCl}_{2}$ addition) was used to differentially vary the 2 mineral forms in $\mathrm{CM}$ (i.e., bound and precipitated). Such additions decrease milk $\mathrm{pH}$, which would be an additional effect on coagulation by modifying the coagulant activity or the charge of caseins. To assess the effects of mineral partition alone, samples were adjusted at $\mathrm{pH} 6.6$ and all experiments, including the mineral titrations, were done at this $\mathrm{pH}$ value. Because $\mathrm{CaHPO}_{4}$ is at saturation in milk $(0.6 \mathrm{mM})$, further $\mathrm{Ca}$ additions result in the formation of $\mathrm{CaHPO}_{4}$ that precipitates as CCP in the CM (Gaucheron, 2005). In contrast, after addition of $10 \mathrm{mM} \mathrm{MgCl}$ in milk, the calculated concentration of $\mathrm{MgHPO}_{4}$ (determined with MilkSalts GLM; Mekmene et al., 2009) using a binding constant of $838 \mathrm{M}^{-1}$ between $\mathrm{Mg}^{2+}$ and $\mathrm{HPO}_{4}{ }^{2-}$ was found to be $1.45 \mathrm{mM}$. Because $\mathrm{MgHPO}_{4}$ has 5 to 6 times higher solubility than $\mathrm{CaHPO}_{4}$ at $20^{\circ} \mathrm{C}$ or $37^{\circ} \mathrm{C}$ (De Bruyne et al., 1990; Gaucheron, 2004), $\mathrm{MgHPO}_{4}$ is not at saturation in the soluble phase of milk (contrary to $\mathrm{CaHPO}_{4}$ ). Thus, there was no precipitation of $\mathrm{MgHPO}_{4}$ in $\mathrm{MgCl}_{2}$-supplemented milk. This is consistent with the models for prediction of mineral equilibria in milk that do not consider exchange of $\mathrm{MgHPO}_{4}$ with $\mathrm{CM}$ (Mekmene et al., 2009; Bijl et al., 2019). Instead, Mg is mainly complexed with citrate (and in a minor proportion with phosphate), in a free ionic state $\left(\mathrm{Mg}^{2+}\right)$ and in interaction with SEP in CM, in the so-called bound form (Table 2). The latter being a direct consequence of the increase of $\mathrm{Mg}^{2+}$ activity because $\mathrm{Mg}^{2+}$ and $\mathrm{Mg}$ bound to SEP are in equilibrium. Thus, after addition of $\mathrm{MgCl}_{2}, \mathrm{Mg}$ was mainly exchanged with $\mathrm{CM}$ through the bound form, whereas $70 \%$ of added Ca precipitated as CCP, providing a relevant and simple mean to study the importance of bound cations and $\mathrm{CPP}$ within $\mathrm{CM}$ during enzymatic coagulation.

The positive control for ionic strength $(10 \mathrm{mM} \mathrm{KCl}$ addition) did not affect mineral partition as shown on Table 1. Addition of $\mathrm{NaCl}$ to milk was reported to increase the concentration of soluble calcium, in the order of $\sim 0.5 \mathrm{~m} M$ for $100 \mathrm{~m} M$ of added $\mathrm{NaCl}$ (Zhao and Corredig, 2015). Assuming that $\mathrm{Na}$ and $\mathrm{K}$ have similar effect on CM, it seems consistent that addition of amounts as low as $10 \mathrm{mM} \mathrm{KCl}$ in milk did not significantly affect mineral partition. As the positive control for ionic strength did not significantly affect the mineral partition nor the coagulation behavior, the effects of $\mathrm{CaCl}_{2}$ and $\mathrm{MgCl}_{2}$ addition can be attributed to the specific effect of $\mathrm{Ca}$ and $\mathrm{Mg}$ ions rather than to the increase of ionic strength. However, there are 2 points to consider before the comparison of the coagulation behaviors of $\mathrm{CaCl}_{2}$ - and $\mathrm{MgCl}_{2}$-supplemented milks.

The first point is the increase of precipitated CCP after $\mathrm{Mg}$ addition (Table 2). After $10 \mathrm{mM} \mathrm{MgCl}_{2}$ addition, $\mathrm{Mg}$ bound to SEP was increased $(+2.6 \mathrm{mM})$ and by competition, displaced some Ca bound to SEP (Table 2). $\mathrm{Mg}^{2+}$ also displaced a fraction of the Ca complexed to citrate. As a result, $\mathrm{Ca}^{2+}$ activity increased and a fraction of the released Ca co-precipitated with phosphate in CM as CCP. This mechanism has already been reported (van Hooydonk and Boerrigter, 1986; Cooke and McSweeney, 2014). Finally, addition of 10 $\mathrm{mM} \mathrm{MgCl} 2$ increased bound cations by $34 \%(+1.7 \mathrm{mM})$ and precipitated CCP by $14 \%(+3 \mathrm{mM})$ against $18 \%$ 


\section{o Standard}

$\square 10 \mathrm{mM} \mathrm{KCl}$

$\triangle 10 \mathrm{mM} \mathrm{MgCl}_{2}$
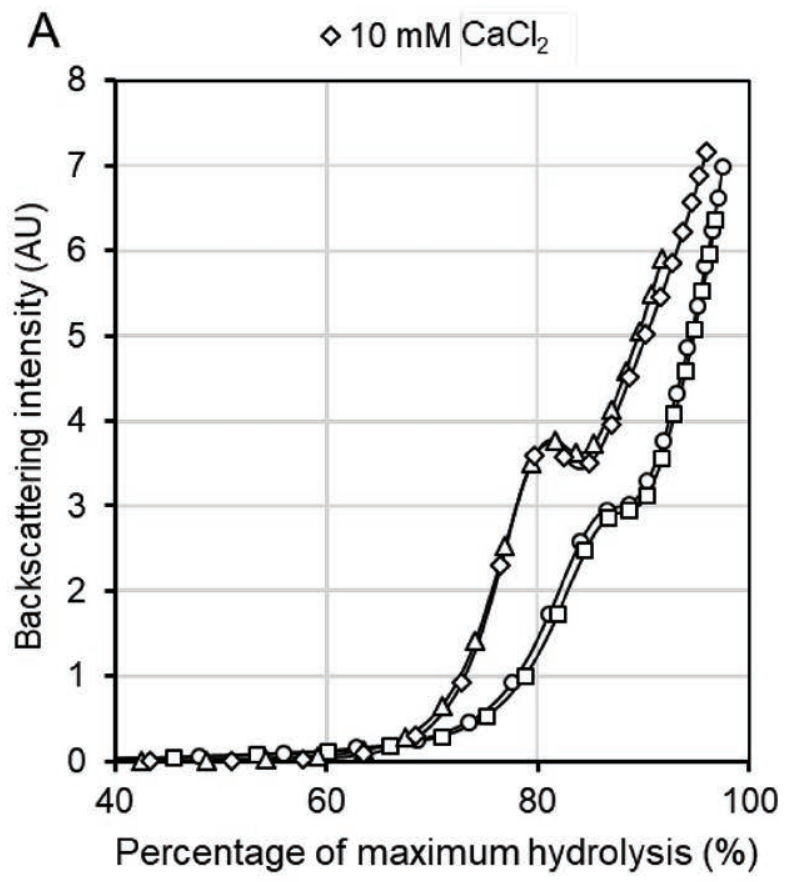

B

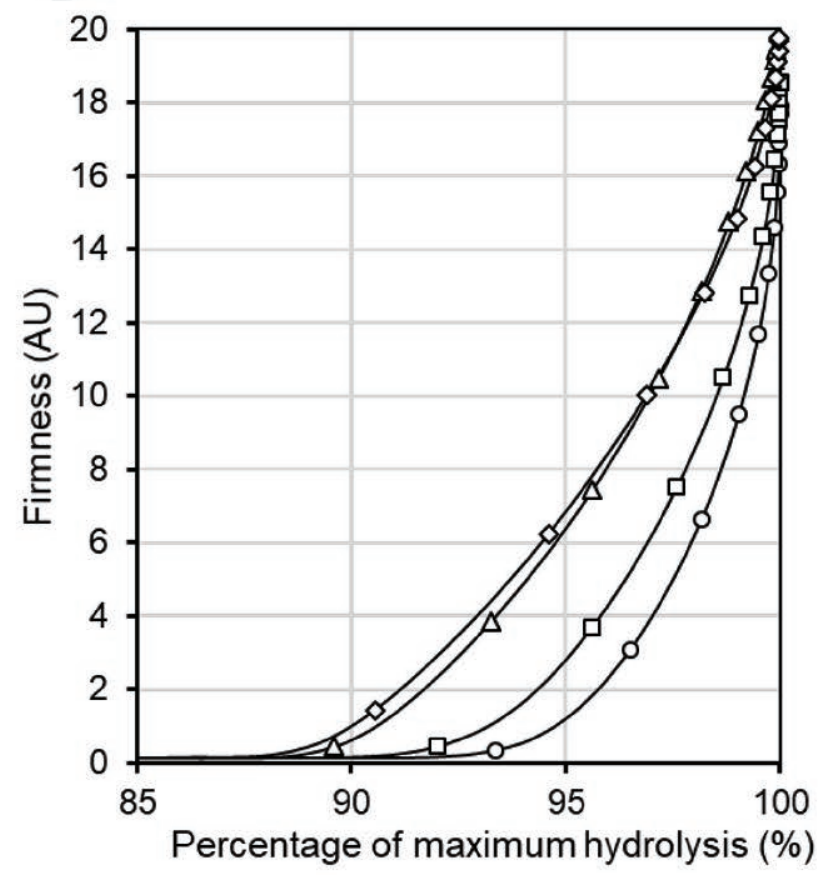

Figure 8. Backscattering intensity (A) and firmness of the gel (B) as a function of the percentage of $\kappa$-casein hydrolysis. Mean of 6 repetitions over 2 sample preparations (B). Low-heat skim milk powder was reconstituted at $3.5 \%$ of proteins. Coagulation was proceeded at $30^{\circ} \mathrm{C}$, $\mathrm{pH}=6.6$, and the coagulant strength was 5,000 international milk clotting units $/ \mathrm{mL}$. AU = arbitrary units.
$(+0.9 \mathrm{mM})$ and $34 \%(+7 \mathrm{~m} M)$ for a $10 \mathrm{mM} \mathrm{CaCl}_{2}$ addition (Figure 4), respectively. However, additions of $\mathrm{CaCl}_{2}$ and $\mathrm{MgCl}_{2}$ to milk still provide systems where bound and precipitated salts in $\mathrm{CM}$ are modified in different ways.

The second point to consider is the effect of salt addition on the kinetics of $\kappa$-casein hydrolysis (Figure 6). Hydrolysis of $\kappa$-casein is the initial step of the enzymatic coagulation of milk and its kinetics influences the following steps that are para-micelles aggregation and gel firming. Therefore, it is risky to discuss the effects of mineral equilibria on aggregation and gel firming without considering the hydrolysis step. The reported effects of $\mathrm{CaCl}_{2}$ addition on the enzymatic hydrolysis of $\mathrm{CM}$ using chymosin are contradictory. $\mathrm{CaCl}_{2}$ has been suggested to increase enzyme activity in milk up to 8 or $40 \mathrm{~m} M$ and then to decrease it (Bringe and Kinsella, 1986; Sun et al., 2014), or to solely decrease it on phosphocaseinate dissolved in water (Famelart and al., 1999). Addition of $\mathrm{CaCl}_{2}$ and $\mathrm{MgCl}_{2}$ at a concentration of $5 \mathrm{~m} M$ was reported to decrease the activity of mucorpepsin from Rhizomucor miehei (da Silva et al., 2016). Based on Figure 6 and Figure 4, we suggested that the activity of the chymosin was hindered by increased concentration of divalent cations in solution. This explains the delay on the gel time observed between $\mathrm{MgCl}_{2^{-}}$and $\mathrm{CaCl}_{2}$-supplemented milk, and the standard milk (Figure 6). The $\mathrm{MgCl}_{2}$-supplemented milk, which showed the highest concentration of divalent cations in solution, exhibited the longest aggregation and gel time (Table 3 ). It has already been reported that $\mathrm{MgCl}_{2}$ was less efficient in reducing the gel time than $\mathrm{CaCl}_{2}$ (Gaucheron, 2004). Unlike our results, Cooke and McSweeney (2014) found that the gel time was reduced at 2.5, 5, and 10 $\mathrm{m} M$ of added $\mathrm{MgCl}_{2}$ but it is likely that coagulants have different sensitivity to divalent cations, as illustrated in the present study (Figure 6). They also used a higher coagulant strength (7,200 international milk clotting units/100 L of milk). In the present work, the representation of the aggregation and gel firming kinetics as a function of the progress of $\kappa$-casein hydrolysis (Figure 8) allows direct comparison of salt additions in milk samples.

With this in mind, it is striking how well the aggregation curves overlapped for $\mathrm{CaCl}_{2^{-}}$and $\mathrm{MgCl}_{2^{-}}$ supplemented milks (Figure 8A). This means that, for a given percentage of $\kappa$-casein hydrolysis, the particle size in both samples similarly evolved and therefore that para-micelles had the same ability to interact and aggregate. In other words, intermicellar interactions were similar in both $\mathrm{CaCl}_{2^{-}}$and $\mathrm{MgCl}_{2}$-supplemented milks. In the dual-binding model for CM structure, it is postulated that the interaction energy between 2 casein monomers or 2 para-micelles depends on the balance of 
a repulsive component, due to casein negative charges, and on an attractive component due to casein ability to associate through hydrophobic bonds (Horne, 1998). In this model, interaction of caseins with CCP decreases the repulsive component by charge shielding and promotes the interaction between caseins and para-casein micelles also. The aggregation behavior of $\mathrm{CaCl}_{2^{-}}$and $\mathrm{MgCl}_{2}$-supplemented milks, that contained different level of bound and precipitated $\mathrm{Ca}$, indicated that both casein-bound cations and precipitated cations decreased the repulsions between para-micelles and promoted aggregation. Moreover, CCP increased by 7 and $3 \mathrm{mM}$ and bound cations ( $\mathrm{Ca}$ and $\mathrm{Mg}$ ) increased by 0.9 and $1.7 \mathrm{mM}$ for $\mathrm{CaCl}_{2}$ - and $\mathrm{MgCl}_{2}$-supplemented milks respectively (Table 2 ). It demonstrates that fewer cations were exchanged after $\mathrm{MgCl}_{2}$ addition, whereas the normalized aggregation kinetics of para-micelles were similar after $\mathrm{CaCl}_{2}$ and $\mathrm{MgCl}_{2}$ addition. Thus, we assumed that cations bound to caseins were more efficient (at equivalent molar concentration) for paramicelle aggregation than their involvement in a salt-like structure such as the nanoclusters (CCP).

Specific casein charge shielding by bound cations explained the effect of $\mathrm{Ca}^{2+}$ on enzymatic coagulation of milk. The concentration of $\mathrm{Ca}^{2+}$ was considered as an important parameter for enzymatic coagulation as a minimal concentration is required for the aggregation of para-micelles to occur (Lucey and Fox, 1993). Udabage et al. (2001) reported that at constant CCP concentration, the gelation properties were increased with $\mathrm{Ca}^{2+}$ activity. Recently, Zhang et al. (2019) indicated that "micellar calcium seems to play a similar role as that of soluble calcium." Interestingly, although the increase of $\mathrm{Ca}^{2+}$ promotes the aggregation of para-micelles, the increase of ionic strength, for concentration of added $\mathrm{NaCl}>20 \mathrm{~m} M$, strongly decreases it (Dalgleish, 1983), and addition of $10 \mathrm{mM} \mathrm{KCl}$ had no effect on aggregation of para-micelles (Table 3). This excludes any nonspecific charge shielding by $\mathrm{Ca}^{2+}$ to modulate para-micelle interactions. The effect of $\mathrm{Ca}^{2+}$ on enzymatic coagulation becomes clear when we consider the equilibrium between $\mathrm{Ca}^{2+}$ and the Ca bound to specific sites of the caseins (i.e., the free SEP residues and glutamic and aspartic acids). In the present work, the $\mathrm{MgCl}_{2}$-supplemented milk and $\mathrm{CaCl}_{2}$-supplemented milk contained different $\mathrm{Ca}^{2+}$ concentrations and different total divalent cation $\left(\mathrm{Ca}^{2+}\right.$ and $\left.\mathrm{Mg}^{2+}\right)$ concentrations (Table 2), but para-micelle aggregation kinetics and coagulation properties were similar (Figure 8). This result supports the fact that $\mathrm{Ca}^{2+}$ or divalent cations concentration are not the prevalent parameters for explaining the enzymatic coagulation properties of milk. Instead, caseinbound cations (mainly with the free SEP residues), the quantity of which correlated with the divalent cation concentration, and precipitated cations together govern the aggregation of para-micelles and coagulation properties of milk.

The gel firmness of $\mathrm{MgCl}_{2}$ - and $\mathrm{CaCl}_{2}$-supplemented milks was higher than the gel firmness obtained with standard milk, in agreement with a higher CCP content that help maintaining the internal stability of CM (Choi et al., 2007; Cooke and McSweeney, 2014). Interestingly, $\mathrm{MgCl}_{2}$ - and $\mathrm{CaCl}_{2}$-supplemented milks had $\mathrm{CM}$ with different CCP contents but they exhibited the same change of gel firmness with the progress of $\kappa$-casein hydrolysis (Figure 8B), at least during the early stages of gel firming. This result indicates that the contribution of bound Ca has also to be considered to explain gel firmness. The role of bound Ca may also be an element of explanation of the maximum gel firmness found after milk acidification to $\mathrm{pH} 6.0$ (Shalabi and Fox, 1982). Milk acidification reduces the zeta potential of the CM, promoting its aggregation. In the same time, a continuous loss of CCP from within CM occurs, which should decrease CM internal stability and reduce gel firmness. However, the $\mathrm{Ca}^{2+}$ activity increases with CCP dissolution and for a small reduction of $\mathrm{pH}$, the amount of bound $\mathrm{Ca}$ increases (confirmed by the modeling of the mineral partitioning with MilksSalt GLM). This Ca bound to casein could reinforce gel firmness by promoting para-micelles interaction. In the opposite, maintaining the concentration of $\mathrm{Ca}^{2+}$ constant (and by extension, the concentration of bound Ca constant) during the acidification of milk seriously decreases the coagulation properties of milk (Shalabi and Fox, 1982). A larger reduction of $\mathrm{pH}$ significantly reduces the affinity between Ca and SEP residue of caseins and the gel becomes weaker. The conversion of $\mathrm{Ca}$ from precipitated CCP to bound Ca upon acidification could explain the observed maximum elastic modulus of the gel between $\mathrm{pH} 6.0$ and 6.4 .

\section{CONCLUSIONS}

Calcium chloride and $\mathrm{MgCl}_{2}$ addition to milk affected differently the concentration of bound cations and precipitated $\mathrm{CCP}$ in the $\mathrm{CM}$. However, the ability of para-micelles to aggregate was similar for both saltsupplemented milks. In view of the dual-binding model, it was deduced that bound cations and the CCP both reduce the electrostatic repulsions between caseins and promote para-micelle aggregation. Considering 2 forms of colloidal $\mathrm{Ca}$ in the dual-binding model also explains the long-known importance of $\mathrm{Ca}^{2+}$ for enzymatic coagulation, as the concentration of bound Ca depends on $\mathrm{Ca}^{2+}$ activity in the soluble phase. These results 
suggest that the role of colloidal Ca for enzymatic coagulation can no longer be interpreted solely based on $\mathrm{CCP}$ variations, especially during acidification where the ionic calcium concentration increases. The role of the 2 colloidal Ca forms on gel structure and its rheological properties remains to be determined. Finally, this study reminds that $\kappa$-casein hydrolysis, being the limiting step during the enzymatic coagulation, affects the all coagulation process. At same coagulant strength, the kinetics of hydrolysis can be different according to the coagulant type and the physicochemical parameters of milk.

\section{ACKNOWLEDGMENTS}

We gratefully acknowledge Chr. Hansen SAS (Hørsholm, Denmark) for the financial support. We also thank Pascaline Hamon for the support provided during the development of the CMP titration method and Eric Beaucher (both of INRAE, Rennes, France), who performed part of the mineral analysis. The authors have not stated any conflicts of interest.

\section{REFERENCES}

Aoki, T., T. Umeda, and Y. Kako. 1992. The least number of phosphate groups for crosslinking of casein by colloidal calcium phosphate. J. Dairy Sci. 75:971-975. https://doi.org/10.3168/jds.S0022 -0302(92)77838-2.

Bijl, E., T. Huppertz, H. van Valenberg, and C. Holt. 2019. A quantitative model of the bovine casein micelle: Ion equilibria and calcium phosphate sequestration by individual caseins in bovine milk. Eur. Biophys. J. 48:45-59. https://doi.org/10.1007/s00249-018-1330-2.

Bouchoux, A., G. Gésan-Guiziou, J. Pérez, and B. Cabane. 2010. How to squeeze a sponge: Casein micelles under osmotic stress, a SAXS study. Biophys. J. 99:3754-3762. https://doi.org/10.1016/j.bpj 2010.10 .019

Bringe, N. A., and J. E. Kinsella. 1986. Influence of calcium chloride on the chymosin-initiated coagulation of casein micelles. J. Dairy Res. 53:371-379. https://doi.org/10.1017/S0022029900024997.

Castillo, M. Z., F. A. Payne, C. L. Hicks, J. S. Laencina, and M. B. M. López. 2003. Modelling casein aggregation and curd firming in goats' milk from backscatter of infrared light. J. Dairy Res. 70:335-348. https://doi.org/10.1017/S0022029903006356.

Choi, J., D. S. Horne, and J. A. Lucey. 2007. Effect of insoluble calcium concentration on rennet coagulation properties of milk. J. Dairy Sci. 90:2612-2623. https://doi.org/10.3168/jds.2006-814.

Choi, J., D. S. Horne, and J. A. Lucey. 2015. Effect of insoluble calcium concentration on endogenous syneresis rate in rennet-coagulated bovine milk. J. Dairy Sci. 98:5955-5966. https://doi.org/10 $.3168 /$ jds.2015-9527.

Cooke, D. R., and P. L. H. McSweeney. 2014. The influence of alkaline earth metal equilibria on the rheological properties of rennetinduced skim milk gels. Dairy Sci. Technol. 94:341-357. https:// doi.org/10.1007/s13594-014-0166-5.

da Silva, R. R., T. B. Souto, T. B. de Oliveira, L. C. G. de Oliveira, D. Karcher, M. A. Juliano, L. Juliano, A. H. C. de Oliveira, A Rodrigues, J. C. Rosa, and H. Cabral. 2016. Evaluation of the catalytic specificity, biochemical properties, and milk clotting abilities of an aspartic peptidase from Rhizomucor miehei. J. Ind. Microbiol. Biotechnol. 43:1059-1069. https://doi.org/10.1007/s10295 $-016-1780-4$
Dalgleish, D. G. 1983. Coagulation of renneted bovine casein micelles: Dependence on temperature, calcium ion concentration and ionic strength. J. Dairy Res. 50:331-340. https://doi.org/10.1017/ S0022029900023165.

De Bruyne, P. A. M., R. M. H. Verbeeck, and F. Verbeek. 1990. The solubility of calcium hydrogen phosphate dihydrate and magnesium hydrogen phosphate trihydrate and ion pair formation in the system $\mathrm{M}(\mathrm{OH})_{2}-\mathrm{H}_{3} \mathrm{Po}_{4}-\mathrm{H}_{2} \mathrm{O}(\mathrm{M}=\mathrm{Ca}$ or $\mathrm{Mg})$ at $37^{\circ} \mathrm{C}$. Bull. des Sociétés Chim. Belges 99:543-552. https://doi.org/10.1002/bscb .19900990805.

de Kruif, C. G. 1998. Supra-aggregates of casein micelles as a prelude to coagulation. J. Dairy Sci. 81:3019-3028. https://doi.org/ 10.3168/jds.S0022-0302(98)75866-7.

Famelart, M. H., Y. Le Graet, and K. Raulot. 1999. Casein micelle dispersions into water, $\mathrm{NaCl}$ and $\mathrm{CaCl}$ : Physicochemical characteristics of micelles and rennet coagulation. Int. Dairy J. 9:293-297. https://doi.org/10.1016/S0958-6946(99)00077-1.

Gaucheron, F. 2004. Minéraux et Produits Laitiers. Tec \& Doc, Paris, France.

Gaucheron, F. 2005. The minerals of milk. Reprod. Nutr. Dev. 45:473483. https://doi.org/10.1051/rnd:2005030.

Gaucheron, F., Y. Le Graet, M. Piot, and E. Boyaval. 1996. Determination of anions of milk by ion chromatography. Lait 76:433-443. https://doi.org/10.1051/lait:1996533.

Hindmarsh, J. P., and P. Watkinson. 2017. Experimental evidence for previously unclassified calcium phosphate structures in the casein micelle. J. Dairy Sci. 100:6938-6948. https://doi.org/10.3168/jds .2017-12623.

Holt, C. 1992. Structure and stability of bovine casein micelles. Adv. Protein Chem. 43:63-151. https://doi.org/10.1016/S0065 $-3233(08) 60554-9$.

Holt, C., D. T. Davies, and A. J. R. Law. 1986. Effects of colloidal calcium phosphate content and free calcium ion concentration in the milk serum on the dissociation of bovine casein micelles. J. Dairy Res. 53:557-572. https://doi.org/10.1017/S0022029900033082.

Horne, D. S. 1998. Casein interactions: Casting light on the black boxes, the structure in dairy products. Int. Dairy J. 8:171-177. https://doi.org/10.1016/S0958-6946(98)00040-5.

Horne, D. S., and J. A. Lucey. 2017. Rennet-induced coagulation of milk. Pages 115-143 in Cheese: Chemistry, Physics and Microbiology. 4th ed. Elsevier Inc., Amsterdam, the Netherlands. https:// doi.org/10.1016/B978-0-12-417012-4.00005-3.

Le Graët, Y., and G. Brulé. 1993. Effects of $\mathrm{pH}$ and ionic strength on distribution of mineral salts in milk. Lait 73:51-60. https://doi .org/10.1051/lait:199312.

Lucey, J. A., and P. F. Fox. 1993. Importance of calcium and phosphate in cheese manufacture: A review. J. Dairy Sci. 76:1714-1724. https://doi.org/10.3168/jds.S0022-0302(93)77504-9.

Malacarne, M., P. Franceschi, P. Formaggioni, S. Sandri, P. Mariani, and A. Summer. 2014. Influence of micellar calcium and phosphorus on rennet coagulation properties of cows milk. J. Dairy Res. 81:129-136. https://doi.org/10.1017/S0022029913000630.

McMahon, D. J., and R. J. Brown. 1982. Evaluation of formagraph for comparing rennet solutions. J. Dairy Sci. 65:1639-1642. https:// doi.org/10.3168/jds.S0022-0302(82)82390-4.

Mekmene, O., Y. Le Graët, and F. Gaucheron. 2009. A model for predicting salt equilibria in milk and mineral-enriched milks. Food Chem. 116:233-239. https://doi.org/10.1016/j.foodchem.2009.02 .039 .

Payne, F. A., and M. Castillo. 2007. Light backscatter sensor applications in milk coagulation. Pages 1-5 in Encyclopedia of Agricultural, Food, and Biological Engineering. D. R. Heldman, ed. Taylor \& Francis, London, UK.

Sandra, S., M. Ho, M. Alexander, and M. Corredig. 2012. Effect of soluble calcium on the renneting properties of casein micelles as measured by rheology and diffusing wave spectroscopy. J. Dairy Sci. 95:75-82. https://doi.org/10.3168/jds.2011-4713.

Schmidt, D. G. 1982. Association of caseins and casein micelle structure. Dev. Dairy Chem. 1:61-86. 
Shalabi, S. I., and P. F. Fox. 1982. Influence of $\mathrm{pH}$ on the rennet coagulation of milk. J. Dairy Res. 49:153-157. https://doi.org/10 $.1017 /$ S0022029900022238.

Sun, Q.. X.-P. Wang, Q.-J. Yan, W. Chen, and Z.-Q. Jiang. 2014. Purification and characterization of a chymosin from Rhizopus microsporus var. rhizopodiformis. Appl. Biochem. Biotechnol. 174:174-185. https://doi.org/10.1007/s12010-014-1044-6.

Thomä, C., I. Krause, and U. Kulozik. 2006. Precipitation behaviour of caseinomacropeptides and their simultaneous determination with whey proteins by RP-HPLC. Int. Dairy J. 16:285-293. https: //doi.org/10.1016/j.idairyj.2005.05.003.

Udabage, P., I. R. McKinnon, and M. A. Augustin. 2001. Effects of mineral salts and calcium chelating agents on the gelation of renneted skim milk. J. Dairy Sci. 84:1569-1575. https://doi.org/10 .3168/jds.S0022-0302(01)74589-4.

van Hooydonk, A. C. M., H. G. Hagedoorn, and I. J. Boerrigter. 1986. The effect of various cations on the renneting of milk. Neth. Milk Dairy J. 40:369-390.

Zhang, Y., Y. Li, P. Wang, Q. Liang, Y. Zhang, and F. Ren. 2019. The factors influencing rennet-induced coagulation properties of yak milk: The importance of micellar calcium during gelation. Lebensm. Wiss. Technol. 111:500-505. https://doi.org/10.1016/j.lwt 2019.05.015.

Zhao, Z., and M. Corredig. 2015. Changes in the physico-chemical properties of casein micelles in the presence of sodium chloride in untreated and concentrated milk protein. Dairy Sci. Technol. 95:87-99. https://doi.org/10.1007/s13594-014-0200-7.

Zoon, P., T. van Vliet, and P. Walstra. 1988. Rheological properties of rennet-induced skim milk gels 3 . The effect of calcium and phosphate. Neth. Milk Dairy J. 42:271-294.

\section{ORCIDS}

J. Bauland (ㄷ https://orcid.org/0000-0003-2514-7116

M. H. Famelart ( https://orcid.org/0000-0002-8682-0485

T. Croguennec 으 https://orcid.org/0000-0003-4720-3641 